Jurnal Ilmu Budaya, Vol. 18, No. 1 Agustus Tahun 2021

\title{
NILAI MORAL PADA FILM NANTI KITA CERITA TENTANG HARI INI KARYA ANGGA DWIMAS SASONGKO
}

\author{
Farah Eka Septyawanti $^{1}$, Elmustian $^{2}$, Hadi Rumadi $^{3}$ \\ ${ }^{12}$ Universitas Riau, Pekanbaru \\ Email:farahekasptywnti@gmail.com ${ }^{1}$, elmustian@lecturer.unri.ac.id ${ }^{2}$, \\ hadi.rumadi@lecturer.unri.ac.id ${ }^{3}$
}

| Abstract

This study aims to describe the moral values contained in the film Nanti Kita Cerita Tentang Hari Ini. This type of research is qualitative research, using descriptive analysis research methods. Data analysis is inductive or qualitative, and the results of the study emphasize meaning rather than generalization. The film Nanti Kita Stories About Today by Angga Dwimas Sasongko, there is a form of moral values in the film, namely individual moral values, which include: honesty, courage, patience, hard work, self-sacrifice, humility., take responsibility, lie. And social moral values which include: cooperation, help, love, deliberation. The researcher found that the results of the data were 60 the number of moral values contained in the dialogue between characters, which were divided into social moral values consisting of honesty 6, courage 6, patience 6, hard work 4, willingness to sacrifice 2, humility 1 , responsibility 8, lying 2 Social moral values consist of: cooperation 2, like to help 2, love 19, deliberation 2. Where the moral value of love is the most found data and humility is the least data found.

Keywords: Moral Value, Film, Nanti Kita Cerita Tentang Hari Ini

\section{Pendahuluan}

Sastra ada untuk dinikmati, dihayati, dipahami, dan dimanfaatkan oleh masyarakat. Sastra memiliki banyak manfaat bagi pembaca misalnya, sastra sebagai sarana hiburan, sastra dapat memperkaya pengetahuan intelektual, sastra sebagai sarana pendidikan, sastra dapat memperkaya serta memperluas emosi pembaca. Biasanya terdapat nilai-nilai yang terkandung di dalamnya, misalnya nilai moral. Nilai ini menyangkut tentang kebaikan, pada setiap individu sangat penting 
memiliki moral yang baik, karena jika setiap individu memiliki moral yang baik, maka hubungan dengan individu lain juga akan terjaga.

Moralitas adalah sifat moral atau keseluruhan asas dan nilai yang berkenaan dengan baik dan buruk (Bertens 2002: 7). Moralitas juga berperan sebagai pengatur dan petunjuk bagi manusia dalam berperilaku agar dapat dikategorikan sebagai manusia yang baik dan dapat menghindari perilaku yang buruk. Baik buruknya perilaku seseorang dapat dilihat melalui moral, moral yang baik dapat tercipta dari lingkungan, terutama dari keluarga. Dapat dipostulatkan bahwa moral adalah akhlak yang terdapat pada diri manusia yang tidak melenceng dari peraturan dan kebiasaan sosial yang mengatur tingkah laku manusia Sastra berisi tentang persoalan yang terjadi pada hidup manusia. Dalam mengungkapannya seorang pengarang secara langsung maupun tidak langsung telah menuangkan persoalan sosial ke dalam karyanya.Sastra terdiri dari beragam bentuk seperti puisi, drama dan film.

Film menjadi salah satu bentuk sastra yang banyak diminati saat ini. Film adalah gambar hidup yang diceritakan bebas oleh pengarangnya namun tetap sesuai dengan norma yang berlaku. Film yang merupakan refleksi dari kehidupan sosial masyarakat ini juga mengandung penerapan moral dalam sikap dan tingkah laku para tokoh sesuai dengan pandangannya tentang moral (Nurgiyantoro, 2013: 430) . Melalui cerita yang ditampilkan dalam film serta sikap dan tingkah laku tokoh dalam film para penonton film diharapkan dapat mengambil pesan-pesan moral yang disampaikan dalam film tersebut.

Film mengungkapkan maksudnya melalui gambar-gambar yang disajikan, selain itu film dianggap memiliki banyak fungsi, seperti bentuk hiburan, dan juga sebagai media komunikasi untuk menyampaikan pesan dari pengarang kepada penontonnya, disinilah 
Jurnal Ilmu Budaya, Vol. 18, No. 1 Agustus Tahun 2021

sutradara dituntut bagaimana

membuat film yang baik agar amanat dan nilai-nilai yang terkandung di dalam film tersebut sampai kepada penonton.

Nilai berkaitan dengan baik dan tidak baiknya perilaku seseorang. Nilai adalah sesuatu yang bersifat abstrak, ideal, nilai bukan benda konkrit, bukan fakta, tidak hanya persoalan benar dan salah yang menuntut pembuktian empirik, melainkan sosial penghayatan yang dikehendaki, disenangi, dan tidak disenangi (Isna, 2001:98). Dalam karya sastra pasti memiliki nilai di dalamnya, salah satu bentuk nilai yang penting ada di dalam sebuah karya adalah nilai moral.

Manusia yang baik adalah manusia yang memiliki sopan santun dengan manusia lainnya. Seperti anak yang berperilaku sopan kepada orang tua dan teman sebayanya. Dengan adanya moral, manusia dapat saling menghormati satu sama lain, dapat menghargai perbedaan pendapat serta moral dapat membentengi diri dari hal buruk. Oleh karena itu, nilai moral sangat penting ada pada setiap individu, terutama generasi muda. Saat ini ada banyak cara untuk menanamkan nilai moral pada masyarakat, salah satunya adalah melalui film. Film yang berkualitas adalah film yang memiliki amanat dan nilai moral di dalamnya sehingga penonton dapat mengambil pelajaran setelah menontonnya. Banyak film yang menyampaikan nilai-nilai moral di dalam ceritanya, salah satunya adalah film keluarga Nanti Kita Cerita Tentang Hari Ini karya Angga Dwimas Sasongko.

Peneliti memfokuskan rumusan masalah yaitu nilai moral apa sajakah yang terdapat pada film Nanti Kita Cerita Tentang Hari Ini karya Angga Dwimas Sasongko. Tujuan yang ingin dicapai dalam penelitian ini adalah untuk mendeskripsikan nilai moral apa sajakah yang terdapat pada film Nanti Kita Cerita Tentang Hari Ini, agar menambah wawasan serta pengetahuan tentang menganalisis 
Jurnal Ilmu Budaya, Vol. 18, No. 1 Agustus Tahun 2021

nilai moral yang terdapat pada film.

Untuk menghindari kesalahpahaman terhadap penelitian yang dilakukan, maka penulis memberikan definisi operasional pada penelitian ini. Nilai Moral adalah nilai yang berlaku dalam suatu lingkungan sosial dan mengatur tingkah laku seseorang. Nilai moral terbagi menjadi dua bentuk yaitu, nirai moral individual dan nilai moral sosial. Film Nanti Kita Cerita Tentang Hari Ini merupakan film yang berdurasi sekitar 121 menit yang disutradarai oleh Angga Dwimas Sasongko. Film ini biasa disebut dengan NKCTHI merupakan film adaptasi dari buku best seller Nanti Kita Cerita Tentang Hari Ini ( NKCTHI) karya Marchella FP yang berisi pesan-pesan pendek tetapi mengandung makna yang dalam bagi pembacanya. Film NKCTHI merupakan film keluarga yang banyak mengandung bentuk nilai moral yang tergambar pada tokoh filmnya.

Terdapat beberapa penelitian relevan dengan penelitian ini. Penelitian relevan pertama tahun 2019
Musdalifatul Makkiyah Mundiri mahasiswa Universitas Nurul Jadid Paiton Probolinggo melakukan penelitian yang berjudul Kontruksi Pendidikan Moral dalam Film Bilal Bin Rabah A New Breed Of Hero karya Ayman Jamal, terdapat pada Jurnal Pendidikan Islam volume 10 nomor 1. Penelitian ini bertujuan untuk mengetahui bagaimana pendidikan moral yang terdapat dalam film Bilal A New Breed Of Hero.

Penelitian relevan kedua pada tahun 2017 Muhammad Firwan mahasiswa Program Studi Pendidikan Bahasa dan Sastra Indonesia, FKIP Universitas Tadulako melakukan penelitian yang berjudul Nilai Moral dalam Novel Sang Pencerah Karya Akmal Nasrey Basral, dimuat pada Jurnal Bahasa dan Sastra volume 2 nomor 2. Hasil dari penelitian yaitu terdapat 4 nilai moral pada novel sang pencerah yaitu : nilai moral antara manusia dengan dirinya sendiri. Nilai moral antara manusia dengan manusia. Nilai moral antara manusia 
Jurnal Ilmu Budaya, Vol. 18, No. 1 Agustus Tahun 2021

dengan alam. Nilai moral antara manusia dengan Tuhan.

Penelitian relevan ketiga pada tahun 2018 dilakukan oleh Dhanang Lukmantoro dkk, mahasiswa Pendidikan Guru Sekolah Dasar Fakultas Ilmu Pendidikan Universitas PGRI Semarang. Penelitiannya berjudul Analisis Nilai Moral Dalam Film Animasi "The Boss Baby" Produksi Dreamworks Animation Bagi Siswa Sekolah Dasar, terdapat pada Jurnal Filsafat Indonesia volume 1 nomor 3. Hasil penelitian yaitu film animasi The Boss Baby mengandung nilai moral yang baik untuk anak-anak seperti: nilai kejujuran, keadilan, toleransi, bijaksana, disiplin diri, suka menolong, berbelas kasih, kerja sama, berani, dan demokratis.

Banyak pelajaran yang didapat serta nilai-nilai moral yang terkandung pada film keluarga ini. Seperti nilai moral individual dan nilai moral sosial. Dengan menonton film ini diharapkan dapat membentuk karakter individu sehingga memiliki nilai moral yang baik dan dapat diterapkan dalam kehidupan terutama generasi muda. Oleh karena itu penulis tertarik untuk meneliti nilai moral yang terdapat pada film Nanti Kita Cerita Tentang Hari Ini. Dalam penelitian ini penulis akan meneliti nilai moral individual dan nilai moral sosial.

\section{Metodologi}

Penelitian ini menjadikan film sebagai objek material. Objek kajian yang digunakan peneliti berupa film Nanti Kita Cerita Tentang Hari ini karya Angga Dwimas Sasongko. Adapun yang menjadi objek formalnya adalah nilai moral yang terkandung pada film tersebut. Pelaksanaan penelitian ini dilakukan dimulai pada bulan Juli 2020 Januari 2021. Perhitungan waktu penelitian diawali dengan pengajuan judul hingga sampai pada tahap ujian sarjana. Penulis memanfaatkan film Nanti Kita Cerita Tentang Hari Ini yang telah penulis unduh pada telegram. 
Jurnal Ilmu Budaya, Vol. 18, No. 1 Agustus Tahun 2021

Jenis penelitian ini adalah penelitian kualitatif, menggunakan metode penelitian analisis deskriptif. Metode penelitian kualitatif adalah metode yang berdasarkan filsafat postpositivisme, sedangkan untuk meneliti pada objek alamiah, dimana peneliti adalah sebagai instrumen kunci, teknik pengumpulan data dilakukan dengan triangulasi (gabungan). Analisis data bersifat induktif atau kualitatif, dan hasil penelitian lebih menekankan makna dari pada generalisasi (Sugiyono, 2011:9). Data dari penelitian ini bersumber pada film Nanti Kita Cerita Tentang Hari Ini yang telah diunduh pada aplikasi telegram, sutradara Angga Dwimas Sasongko, produser Anggia Kharisma, film berdurasi selama 121 menit, tanggal liris 2 Januari 2020, menggunakan Bahasa Indonesia. Peneliti menggunakan teknik pengumpul data berupa kajian dokumen film Nanti Kita Cerita Tentang Hari Ini. Adapun tahap yang dilakukan oleh peneliti adalah: Pertama, mengidentifikasi data yang termasuk nilai moral individual dan nilai moral sosial dalam film Nanti Kita Cerita Tentang hari Ini. Kedua, mengklasifikasi data yang termasuk nilai moral individual dan nilai moral sosial dalam film Nanti Kita Cerita Tentang hari Ini. Berdasarkan teknik pengumpulan data yang dipergunakan maka data dianalisis dengan menggunakan analisis deskriptif. Berdasarkan nilai moral yang dijadikan acuan penelitian meliputi: pertama, mendeskripsikan data yang termasuk nilai moral individual dan nilai moral sosial dalam film Nanti Kita Cerita Tentang Hari Ini, kedua membahas data yang termasuk nilai moral individual dan nilai moral sosial dalam film Nanti Kita Cerita Tentang hari Ini. Ketiga, menyimpulkan hasil analisis nilai moral individual dan nilai moral sosial dalam film Nanti Kita Cerita Tentang Hari Ini.

\section{Hasil dan Pembahasan}

\section{Hasil}


Jurnal Ilmu Budaya, Vol. 18, No. 1 Agustus Tahun 2021

Sesuai dengan tujuan penelitian yang ingin dicapai dalam mengkaji film Nanti Kita Cerita Tentang Hari Ini karya Angga Dwimas Sasongko, hasil penelitian sebagai berikut. Pertama, terdapat wujud nilai moral individual dalam film Nanti Kita Cerita Tentang Hari Ini. Kedua, terdapat wujud nilai moral sosial film Nanti Kita Cerita Tentang Hari Ini. Hasil penelitian ini disusun dalam bentuk tabel-tabel yang kemudian dideskripsikan dalam pembahasan, untuk lebih jelasnya, hasil pembahasan dipaparkan sebagai berikut:

\section{Film Nanti Kita Cerita}

Tentang Hari Ini mengandung wujud nilai moral individual yaitu nilai moral yang tertanam pada setiap diri individu yang meliputi : kejujuran, keberanian, kesabaran, kerja keras, rela berkorban, kerendahan hati, bertanggung jawab, berbohong. Adapun wujud nilai moral sosial yaitu bagaimana cara seseorang bergaul dan berinteraksi dengan individu lain yang meliputi: kerja sama, suka menolong, kasih sayang, dan musyawarah.

Peneliti menemukan hasil data 60 jumlah nilai moral yang terdapat pada dialog antar tokoh, yang terbagi menjadi nilai moral sosial terdiri dari kejujuran 6 , keberanian 6 , kesabaran 6 , kerja keras 4, rela berkorban 2, kerendahan hati 1 , bertanggung jawab 8 , berbohong 2. Nilai moral sosial terdiri dari: kerja sama 2, suka menolong 2, kasih sayang 19, musyawarah 2. Dimana nilai moral kasih sayang adalah data yang paling banyak ditemukan dan kerendahan hati merupakan data yang paling sedikit ditemukan.

\section{Nilai Moral Individual}

\section{Kejujuran}

Kejujuran merupakan suatu kebijakan pada setiap diri manusia. Kejujuran mencerminkan kesesuaian antara hati, sikap dan perbuatan manusia, setiap manusia seharusnya memiliki sifat jujur, karena sifat tersebut dapat membawa manusia ke status sosial yang lebih baik, 
seseorang yang selalu bersikap jujur maka akan dipercaya dan disenangi orang lain. Jujur adalah perilaku yang didasarkan pada upaya menjadikan dirinya sebagai orang yang selalu dapat dipercaya dalam perkataan, tindakan, dan pekerjaan, baik terhadap dirinya maupun pihak lain (Mustari, 2011:13-15). Data yang ditemukan peneliti adalah sebagai berikut;

$$
\begin{gathered}
A \text { : “Ada apa sebenarnya di } \\
\text { rumah ini yang ngga aku } \\
\text { tau?" } \\
B \text { : "Ra, Awan sebenarnya } \\
\text { punya saudara kembar. } \\
\text { Kita semua punya adik } \\
\text { yang gapernah kita kenal." } \\
\text { (01:21:23)-(01:21:48) }
\end{gathered}
$$

Dialog di atas menjelaskan tentang Angkasa yang memberitahu Awan dan Aurora bahwa sebenarnya Awan mempunyai saudara kembar yang sudah meninggal. Rahasia ini telah disimpan oleh Angkasa, Ibu, dan Ayah mereka selama bertahun-tahun agar mereka tidak perlu mengingat dan merasakan sedih di kemudian hari. Angkasa sebagai abang di beri kepercayaan oleh Ayahnya agar dapat merahasiakan ini kepada adik-adiknya yaitu Awan dan Aurora. Tetapi karena
Angkasa merasa bahwa Awan dan Aurora harus tahu tentang masalah ini maka ia pun memberitahu mereka walaupun harus bertengkar dengan ayahnya. Dan pada dialog diatas terdapat nilai moral sosial kejujuran, terdapat pada kalimat " $R a, A w a n$ sebenarnya punya saudara kembar. Kita semua punya adik yang ga pernah kita kenal.",

\section{Keberanian}

Sifat keberanian tidak dimiliki pada setiap individu, namun setiap manusia dituntut untuk berani, karena dengan keberanian maka manusia dapat bertahan hidup. Seseorang yang mempunyai keberanian yang tinggi berarti juga mempunyai rasa percaya diri yang tinggi. Dengan keberanian yang tinggi, seseorang berarti siap mengambil resiko yang besar dalam hidupnya. Data yang ditemukan peneliti adalah sebagai berikut;

A:"Aku ga pernah minta diantar jemput kok, aku bisa pulang sendiri."

B: Mulai besok kamu ngga akan lagi pulang sendirian mas Angkasa yang akan 
Jurnal Ilmu Budaya, Vol. 18, No. 1 Agustus Tahun 2021

jeтриt kaти setiap hari. (27:36)

Dialog di atas menjelaskan tentang Awan yang selalu diantar jemput oleh Angkasa ketika pergi dan pulang dari kantor. Ketika Awan mengalami kecelakaan, Angkasa dimarahi oleh Ayahnya karena tidak menjemput Awan di kantor. Melihat Angkasa yang dimarahi Awan pun menjelaskan kepada Ayahnya bahwa ia tidak perlu untuk diantar jemput ketika bekerja, karena ia bisa melakukannya sendiri, nilai moral individual keberanian terdapat pada kalimat "Aku bisa pulang sendiri."

\section{Kesabaran}

Sabar artinya dapat menahan diri dari keinginan, emosi tanpa adanya keluhan. Dalam kehidupan manusia banyak dihadapkan dengan permasalahan dan cobaan maka sikap sabar sangat membantu dalam menghadapi permasalahan tersebut. Data yang ditemukan peneliti adalah sebagai berikut;

$$
\begin{gathered}
\text { A : “Jadi ini yang namanya } \\
\text { Sekala." }
\end{gathered}
$$

B: "Makasih loh ayah udah nyempatin datang kesini." (01:10:08)

Dialog di atas menjelaskan tentang Aurora yang mengadakan pameran seni pertamanya. Tetapi pada saat itu Awan belum datang dan tidak dapat dihubungi, hal itu membuat Sang Ayah marah kepada Angkasa karena Angkasa tidak menjaga Awan, melihat Ayahnya dan Angkasa yang bertengkar di pameran seninya Aurora dengan sabar tetap berterima kasih kepada Ayahnya karena sudah menyempatkan waktu untuk datang, terlihat muka sedih Aurora tetapi ia berusaha untuk tidak marah kepada ayahnya dan bersikap sabar. Dapat dilihat pada menit (01:10:08) Aurora yang berkata kepada Ayahnya terima kasih sudah datang dengan tersenyum.

\section{Kerja Keras}

Ketika mempunyai keinginan yang besar dan sangat ingin untuk dicapai, maka bekerja keras sangat diperlukan untuk mencapai target tersebut. Keinginan yang besar mesti disertai dengan usaha yang besar. 
Data yang ditemukan peneliti adalah sebagai berikut;

$$
\begin{aligned}
& \text { A: "Minggu lalu kamu } 1.30 \\
& \text { detik... Minggu depan } 1.28 \\
& \text { sanggup?" } \\
& \text { B: "Sanggup coach." } \\
& \text { (15:18)-(15:28) }
\end{aligned}
$$

Dialog di atas menjelaskan tentang Aurora yang sedang berlath untuk perlombaan renang dan ia mencetak rekor tertinggi disaat latihan renang, dan pelatihnya memberi nasehat agar lebih giat berlatih lagi agar dapat juara, selain nasehat pelatihnya juga memberikan tantangan kepada Aurora agar dapat mencetak rekor baru yaitu 1.28 detik. Dengan semangatnya untuk juara maka Aurora dengan yakin menyanggupi tantangan pelatihnya tersebut.

\section{Rela Berkorban}

Sikap rela berkorban berarti melakukan sesuatu untuk kepentingan orang banyak yang dilakukan dengan hati yang ikhlas dan lapang tanpa menuntut suatu imbalan. Data yang ditemukan peneliti adalah sebagai berikut;
A: "Awan ga pernah minta Ayah untuk manfaatin nasabah Ayah."

$\begin{array}{cc}\text { B: "Ayah } & \text { pertaruhkan } \\ \text { hubungan } & \text { propesional }\end{array}$ kerja ayah supaya kamu dapat pekerjaan yang kamu impikan." (57:58)

Dialog ini menjelaskan tentang Ayahnya Awan, Angkasa dan Aurora yang mempertaruhkan hubungan profesional pekerjaannya agar Awan mendapat pekerjaan yang dia inginkan. Disaat sang ayah mengetahui Awan dipecat dari pekerjaannya, maka ayahnya menggunakan kekuasaanya agar Awan mendapatkan tawaran pekerjaan kerjasama kembali dari kantornya dulu. Mengetahui itu Awan sangat marah kepada ayahnya namun ayahnya merasa perbuatannya itu agar Awan mendapatkan pekerjaan yang dia impikan sejak dulu.

\section{Kerendahan Hati}

Kerendahan hati merupakan sikap tidak menyombongkan diri karena menyadari keterbatasan diri dan menyadari bahwa setiap orang mempunyai kekurangannya masing- 
Jurnal Ilmu Budaya, Vol. 18, No. 1 Agustus Tahun 2021

masing. Pada Film Nanti Kita Cerita

Tentang Hari Ini peneliti tidak menemukan data kerendahan hati, karena tidak adanya tuturan yang menggambarkan nilai moral kerendahan hati di dalam film tersebut.

\section{Bertanggung Jawab}

Bertanggung jawab merupakan kesadaran diri yang dimiliki manusia atas perilaku yang dilakukannya. Setiap orang harus memiliki sikap bertanggung jawab, karena bertanggung jawab merupakan ciri manusia yang beradab dan berbudaya. Data yang ditemukan peneliti adalah sebagai berikut;

\section{A: "Kalau misalnya ayah dan ibu ga ada yang jagain adik-adik siapa?" \\ B : "Angkasa." (42:32)}

Dialog di atas menjelaskan tentang Sang Ayah yang mengajarkan Angkasa agar bertanggung jawab sedari kecil, karena ia merupakan kakak tertua maka nanti jika tidak ada kedua orang tuanya yang akan menjaga adik-adiknya adalah Angkasa. Dan Angkasa sudah mengerti tanggung jawabnya sebagai abang walaupun ia masih kecil. Hal ini dapat dilihat di sepanjang film Ayahnya selalu meminta Angkasa untuk bertanggung jawab sebagai seorang abang. Nilai moral individual bertanggung jawab pada dialog di atas terlihat disaat angkasa menjawab pertanyaan Ayahnya, bawah ialah yang akan menjaga adik-adiknya.

\section{Berbohong}

Berbohong berarti mengatakan sesuatu yang tidak terbukti kebenarannya, berbohong merupakan sikap yang tidak terpuji, jika seseorang sering berbohong maka orang tersebut akan sulit mendapat kepercayaan dari orang lain.

A : "Ayah tadi nyuruh jemput kamu di kantor, bukan disini."

B : "ya udah sih, ayah juga ga bakal tau ini, ntar kalau telat bilang aja macet." (08:35)-(08:41)

Dialog di atas menjelaskan tentang Awan dan Angkasa yang berbohong kepada Ayahnya karena mereka tidak mengikuti perintah 
Jurnal Ilmu Budaya, Vol. 18, No. 1 Agustus Tahun 2021

Ayahnya agar Awan dijemput dikantor

bukan di stasiun. Awan ingin dijemput

di stasiun karena ingin pulang bersama teman-temannya dan Angkasa menuruti permintaan Awan tersebut tetapi jangan sampai Ayah mereka tahu. Berbohong merupakan nilai moral yang tidak boleh ditiru tetapi ini dapat dijadikan pelajaran bagi yang menonton bahwa itu perbuatan yang tidak baik. Pada dialog tersebut berbohong terdapat pada tuturan yang dikatakan oleh awan yaitu "Ntar kalau telat bilang aja macet."

\section{Nilai Moral Sosial}

\section{Kerja sama}

Kerja sama berarti melakukan suatu pekerjaan secara bersama-sama antara dua orang atau lebih agar terasa lebih ringan. Bekerja sama dilakukan untuk mencapai suatu tujuan yang sama, karena pada hakikatnya manusia tidak bisa hidup sendiri dan membutuhkan bantuan orang lain.

$$
\begin{aligned}
& \text { A: "Kamu masih ngerjain } \\
& \text { maket? Nanti kita kerjain } \\
& \text { sama-sama ya." } \\
& \text { B:"Awan bisa kerjain } \\
& \text { sendiri." }
\end{aligned}
$$
A:" Buat apa ada keluarga kalau semuanya mau dikerjain sendiri.' (12:56)- (13:02)

Dialog di atas menceritakan tentang Awan yang tidak bisa ikut acara makan malam keluarga di restoran karena ia ada kerjaan yang akan dipresentasikan lusa. Mengetahui anaknya sedang mengerjakan deadline kerjaan sang ayah menawarkan diri untuk membantu Awan karena menurut ayahnya untuk apa kerja sendiri jika ada keluarga yang bisa membantu. Terlihat sikap kerja sama antara ayah dan anak pada dialog diatas ketika sang Ayah ingin membantu Awan untuk mengerjakan maketnya.

\section{Suka Menolong}

Suka menolong merupakan sikap terpuji yang dimiliki oleh manusia, jika seseorang merasa kesulitan maka akan ada gerakan dari hati manusia yang peka untuk membantu. Permasalahan yang dihadapi akan terasa lebih ringan, atau masalah tersebut dapat terpecahkan. 
Jurnal Ilmu Budaya, Vol. 18, No. 1 Agustus Tahun 2021

"Kamu kalau butuh orang untuk menghibur atau nemenin kamu saat kamu butuh, aku bisa."

(01:37:31)

Dialog di atas menjelaskan tentang Kale yang memberikan pernyataan kepada Awan jika ia butuh pertolongan maka Kale akan siap membantunya. Disini tergambar sikap suka menolong yang ada pada diri Kale. Dapat dilihat ketika Kale mengatakan "Кати kalau butuh orang untuk menghibur atau nemenin kamu saat kamu butuh, aku bisa." kepada Awan. Pada tuturan tersebut terlihat sikap suka menolong pada diri Kale.

\section{Kasih Sayang}

Kasih sayang adalah sikap yang dianugerahkan oleh tuhan untuk menghormati manusia lainnya. Kasih sayang merupakan perasaan emosional yang melibatkan hati pada satu individu dengan individu lainnya, kasih sayang banyak jenisnya salah satunya kasih sayang yang didapat dari keluarga.
A: Yah kata coach catatan waktu aku paling baik diantara yang lain."

B: "Hebat anak ibu." (15:44)-(16:27)

Dialog di atas menjelaskan tentang Aurora yang baru saja mencetak waktu tertinggi dalam latihan renangnya, namun disaat ia membanggakan kepada Ayahnya, respon yang diberikan Ayahnya tidak sesuai dengan harapan Aurora. Melihat raut wajah Aurora yang sedih, Ajeng ibunya mengucapkan kata kasih sayang untuk mengapresiasi sesuatu yang telah Aurora capai sehingga Aurora tidak merasa sedih, dengan berkata bahwa Aurora adalah anak yang hebat sambil memeluk dan menciumnya.

\section{Musyawarah}

Musyawarah berarti kegiatan berkumpul bersama sambil bertukar pikiran untuk membicarakan suatu permasalahan agar terciptanya sebuah kesepakan dan tercapainya suatu kesepakatan bersama. 
Jurnal Ilmu Budaya, Vol. 18, No. 1 Agustus Tahun 2021

"Saya rasa saya perlu mengumpulkan kalian di sini semua, setelah kejadian di pameran tadi."

(01:17:10)

Tuturan di atas menjelaskan tentang ayah yang mengumpulkan anak-anaknya yaitu Angkasa, Aurora dan Awan di ruang keluarga untuk membicarakan masalah yang telah terjadi di pameran seni pertama Aurora tadi. Menurutnya ia sebagai kepala keluarga harus berbicara secara kekeluargaan dengan tiga orang anaknya serta istrinya agar masalah yang ada di keluarga itu cepat selesai dan tidak terjadi kesalahpahaman. Musyawarah terjadi ketika mereka semua berkumpul di ruang tamu untuk menyelesaikan masalah keluarga mereka.

\section{Pembahasan}

Bahasa yang digunakan seseorang tentu mencerminkan sifat dan moral yang dimilikinya, oleh karena itu diperlukan adanya nilai moral positif yang tertanam pada diri individu sehingga dapat dijadikan pembelajaran yang baik dalam penerapan kehidupan sehari-hari. Pendayagunaan bahasa dalam pengungkapan nilai moral individual sebagai mana seseorang dalam berkomunikasi, apa yang diujarkan akan menggambarkan sifat yang mencerminkan budi pekerti yang dimiliki. Penggunaan bahasa yang baik akan memunculkan nilai moral yang baik pula terhadap diri sendiri. Hal tersebut juga menjadi acuan untuk terus dapat mendayagunakan bahasa yang baik untuk memberikan nilai moral yang baik pula.

Pendayagunaan bahasa dalam pengungkapan nilai moral sosial dilihat dari bagaimana seseorang berkomunikasi dan berinteraksi dengan masyarakat, karena bahasa yang diujarkan oleh setiap individu merupakan hasil pikiran dan kepribadian seseorang dapat dilihat dari bahasa yang digunakannya. Jika individu tersebut menggunakan bahasa yang baik kepada individu lainnya, maka terciptalah lingkungan yang aman dan tentram karena bahasa sangat mempengaruhi interaksi 
Jurnal Ilmu Budaya, Vol. 18, No. 1 Agustus Tahun 2021

terhadap sesama. Pendayagunaaan

bahasa yang baik akan mencerminkan

nilai moral yang baik di lingkungan tersebut.

Moral berfungsi sebagai pembentukan karakter pada setiap individu. Moral dipengaruhi oleh lingkungan sekitar seperti lingkungan keluarga, dan lingkungan masyarakat baik dari pengaruh positif maupun pengaruh negatif. Karakter dapat diartikan sebagai ciri khas yang dimiliki oleh seseorang. Karakter juga merupakan bentuk budi pekerti yang dimiliki oleh setiap individu yang menjadi pembeda dengan individu lainnya. Nilai moral yang bersifat positif sangat penting ada pada setiap individu, nilai moral tersebut terbagi menjadi nilai moral individual dan nilai moral sosial.

Peran nilai moral individual pada pembentukan karakter dapat dilihat dari bagaimana seseorang tersebut memperlakukan diri sendiri dengan baik dan menjauhi hal yang merugikan diri sendiri, mengerti tindakan apa yang harus diambil, dan memberikan prioritas pada hal-hal yang bersifat postif. Jika seseorang tersebut mempunyai nilai moral yang baik pada dirinya maka menggambarkan karakter yang baik.

Peran nilai moral sosial pada pembentukan karakter dilihat bagaimana seorang individu berinteraksi dengan masyarakat sekitar, nilai moral yang bersifat positif sangat diperlukan agar seseorang mempunyai rasa toleransi yang tinggi sehingga mencerminkan kehidupan yang demokratis, aman dan tertib.

Film merupakan sebuah cerita yang diperankan oleh tokoh tertentu dibuat dengan terstruktur dan utuh. Film banyak digemari karena menampilkan gambaran yang bergerak sehingga dapat ditonton, film yang baik mempunyai amanat yang dapat diamalkan pada kehidupan sehari-hari bagi seseorang orang yang menontonnya. Di dalam film terdapat nilai-nilai yang bisa diambil seperti nilai moral. Film menjadi wadah 
penanaman nilai moral yang efektif pada generasi muda.

Penanaman nilai moral pada film Nanti Kita Cerita Tentang Hari Ini dapat dilihat dari sifat penyayang, kesabaran, kerja keras, rela berkorban yang dimiliki oleh setiap tokoh yang terdapat pada film tersebut. Selain itu juga dapat dilihat kasih sayang antara orang tua untuk anak-anaknya, kasih sayang saudara, tanggung jawab saudara laki-laki untuk selalu menjaga adik-adiknya dan juga sikap tanggung jawab yang dimiliki seorang Ayah agar keluarganya hidup tentram. Nilai moral yang ada pada film (NKTCHI) dapat diterapkan dalam kehidupan sehari-hari.

Film Nanti Kita Cerita Tentang Hari Ini atau biasa disebut dengan (NKCTHI) merupakan film adaptasi dari sebuah buku karya Marchella FP. Film ini di sutradarai oleh Angga Dwimas Sasongko, berbeda dengan adaptasi film lainnya, buku NKCTHI hanya berisikan pesan-pesan motivasi bagi seseorang yang membacanya. Kata-kata yang menyentuh di dalam buku ini kemudian dijadikan sebuah skenario berwujud cerita utuh oleh Angga Dwimas Sasongko. Aktor dan artis pada film ini merupakan pemain profesional di ranah film Indonesia sehingga tidak diragukan lagi makna cerita yang disampaikan di dalam film dapat sampai pada penonton.

Film Nanti Kita Cerita Tentang Hari Ini menceritakan tentang drama keluarga antara orang tua dan ketiga anaknya yang bernama Angkasa, Aurora, dan Awan. Film ini berisi tentang keinginan orang tua yang tidak sejalan dengan pilihan anak, kerap kali orang tua hanya memberikan apa yang dianggapnya benar untuk membuat anaknya bahagia, padahal belum tentu semua itu benar. Namun dari pandangan orang tua hal tersebut mereka lakukan agar anak-anaknya bahagia.

Film Nanti Kita Cerita Tentang Hari Ini secara umum dapat mengaduk emosi penontonya. Dengan pilihan alur maju mundur Angga Dwimas Sasongko berusaha menyampaikan pesan lewat ekspresi para pemain. 
Salah satu yang paling berhasil disampaikan oleh Aurora dengan jelas adalah sikap sabar dan bekerja keras. Hal tersebut terlihat jelas jika menonton film ini.

Banyak nilai moral yang terdapat pada film ini. Nucci, L dan Marverez (2008) menyebutkan bahwa bentuk nilai moral terdiri dari nilai moral individual dan nilai moral sosial. Nilai moral individual berkaitan langsung dengan diri sendiri, dimana individu tersebut yang menentukan sikap dan perilakunya terhadap dirinya sendiri, sedangkan nilai moral sosial merupakan perilaku atau sikap manusia dengan manusia lainnya didalam masyarakat.

Film Nanti Kita Cerita Tentang Hari Ini karya Angga Dwimas Sasongko mengandung dua bentuk nilai moral yaitu nilai moral individual dan nilai moral sosial. Kedua nilai tersebut didapatkan dari tuturan yang disampaikan oleh tokoh di dalam film, yang mana film tersebut tidak melibatkan tokoh antagonis di dalamnya. Semua tokoh pada film ini merupakan tokoh protagonis, oleh karena itu banyak mengandung nilai moral yang disampaikan dengan baik sehingga dapat dijadikan pembelajaran bagi penikmatnya.

Pada film ini nilai moral individual berupa bertanggung jawab paling banyak dijumpai, dapat dilihat dari bagaimana seorang Ayah yang mengajarkan tanggung jawab kepada anak laki-lakinya yaitu Angkasa untuk selalu menjaga dan menyayangi adikadiknya, tidak hanya itu keberanian, kesabaran, dan kerja keras rela berkorban, kerendahan hati juga tersampaikan dengan jelas oleh para pemainnya sehingga itu juga dapat di terapkan di kehidupan sehari-hari oleh penonton. Terdapat nilai moral berbohong, dapat dijadikan pembelajaran bahwa ini tidak untuk ditiru namun dipahami bahwa berbohong merupakan sesuatu yang tidak baik, tentu itu harus dihindari pada pribadi seseorang agar tidak merugikan orang lain dan dirinya sendiri. 
Jurnal Ilmu Budaya, Vol. 18, No. 1 Agustus Tahun 2021

Pada film Nanti Kita Cerita

Tentang Hari Ini nilai moral sosial kasih sayang paling banyak dijumpai hal ini tergambar dari kasih sayang seorang Ayah untuk ketiga anaknya, kasih sayang seorang suami dan istri, kasih sayang oleh saudara kandung dan kasih sayang oleh ibu dan anak. Kerja sama, suka menolong, musyawarah juga dapat dijumpai pada film dan itu menggambarkan bagaimana pemain bersosialisasi pada orang sekitarnya. Nilai moral tersebut dapat dijadikan contoh dalam kehidupan sehari-hari agar setiap individu dapat bersosialisasi dengan individu lainnya dengan baik, dan nilai moral yang baik tentu juga akan tertanam pada setiap individu.

\section{Simpulan}

Berdasarkan analisis data penelitian yang telah dilakukan, maka simpulan yang diperoleh sebagai berikut:

Film adalah gambar hidup yang diceritakan bebas oleh pengarangnya namun tetap sesuai dengan norma yang berlaku. Film Nanti Kita Cerita Tentang Hari Ini karya Angga Dwimas Sasongko mengandung nilai moral. Wujud nilai moral yang ada di dalam film yaitu nilai moral individual dan nilai moral sosial. Nilai moral individual adalah nilai moral yang tertanam pada setiap diri individu yang meliputi: kejujuran, keberanian, kesabaran, kerja keras, rela berkorban, kerendahan hati, bertanggung jawab, berbohong. Adapun nilai moral sosial yaitu bagaimana cara seseorang bergaul dan berinteraksi dengan individu lain yang meliput: kerja sama, suka menolong, kasih sayang, musyawarah.

\section{Daftar Pustaka}

Bertens, K. (2007). Etika. Jakarta: PT Gramedia Pustaka Utama.

Firwan, Muhammad. (2017). Nilai Moral dalam Novel Sang Pencerah Karya Akmal Nasrey Basral. Jurnal Bahasa dan Sastra: 2(2): 49-50.

Lukmantoro, Dhanang dkk. (2018). Nilai Moral Dalam Film Animasi "The Boss Baby" Produksi Dreamworks Animation Bagi Siswa 
Jurnal Ilmu Budaya, Vol. 18, No. 1 Agustus Tahun 2021

Sekolah Dasar. Jurnal Filsafat Indonesia: 1(3): 128-133.

Mundiri, Musdalifatul Makkiyah. (2019). Kontruksi Pendidikan Moral dalam Film Bilal Bin Rabah A New Breed Of Hero Karya Ayman Jamal. Jurnal Pendidikan Islam. 10 (1): 3149.

Mansur Isna. (2001). Diskursus Pendidikan Islam. Yogyakarta: Global Pustaka Utama.
Mohamad, Mustari. (2011). Nilai Karakter. Yogyakarta : LaksBang PRESSindo.

Nurgiyantoro, Burhan. (2013). Teori Pengkajian Fiksi. Yogyakarta: Gadjah Mada, Universitas Press.

Sugiyono. (2011). Metode Penelitian Kuantitatif, Kualitatif dan $R \& D$. Bandung: Alfabeta. 